\title{
Sleep-disordered breathing in children with asthma: a systematic review on the impact of treatment
}

This article was published in the following Dove Press journal:

Journal of Asthma and Allergy

18 April 2016

Number of times this article has been viewed

\author{
Trinidad Sánchez' \\ José A Castro-Rodríguez ${ }^{2}$ \\ Pablo E Brockmann ${ }^{2,3}$ \\ 'Division of Pediatrics, School of \\ Medicine, ${ }^{2}$ Department of Pediatric \\ Cardiology and Pulmonology, Division \\ of Pediatrics, School of Medicine, \\ ${ }^{3}$ Sleep Medicine Center, Department \\ of Neurology, School of Medicine, \\ Pontificia Universidad Católica de \\ Chile, Santiago, Chile
}

Background: The objective was to perform a systematic review in order to describe the relationship between asthma and sleep-disordered breathing (SDB) in children, especially regarding the impact of treatment and management.

Methods: We performed an electronic search in MEDLINE, EMBASE, and LILACS database. Study inclusion criteria were the following: 1) studies that examined the relationship between asthma/wheezing and SDB/obstructive sleep apnea (OSA); and 2) studies conducted in children $<18$ years of age. Primary outcomes were the prevalence of asthma and SDB, the tests used for diagnosis, and the influence of their treatment and management.

Results: One thousand and twenty studies were identified, among which 32 were selected ( $n=143,343$ children; $51 \%$ males; age [mean \pm standard deviation] 8.4 \pm 2.5 years). Most studies $(n=26)$ diagnosed SDB using questionnaires or clinical history. Nine studies performed a sleep study for diagnosing OSA. The diagnosis of asthma was based on clinical history $(n=16)$, previous medical diagnosis $(n=4)$, questionnaires $(n=12)$, and spirometry $(n=5)$. Children with asthma were more likely to develop habitual snoring and OSA, and children with SDB were more likely to develop asthma. Moreover, asthma was associated with more severe OSA, and the presence of SDB was associated with severe asthma. Treatment of SDB with adenotonsillectomy was associated with significant asthma improvement.

Conclusion: The relationship between asthma and SDB appears to be bidirectional, and adenotonsillectomy appears to improve asthma control. Future trials on how asthma treatment could impact on SDB are needed.

Keywords: obstructive sleep apnea, wheezing, children, Asthma, sleep-disordered breathing

\section{Introduction}

Asthma is known to be one of the most common chronic diseases in childhood. ${ }^{1}$ Asthma most frequently starts early in life and has a variable clinical evolution and different phenotypes which may progress or remit over time. ${ }^{2}$ Around half of preschool wheezers become asymptomatic by school age irrespective of treatment. ${ }^{3}$ However, asthma symptoms (eg, sleep disturbance and cough at night) may persist, often lifelong, especially among atopic children and in more severe cases. The impact of asthma on the quality of life and health cost of patients is very high., ${ }^{4,5}$ Therefore, appropriate asthma management may have a major impact on the quality of life of patients and their families, as well as on public health outcomes. ${ }^{3}$

On the other hand, sleep-disordered breathing (SDB) is also a prevalent disease in children. ${ }^{6}$ Similar to asthma, SDB has a broad clinical presentation, ranging from primary snoring to obstructive sleep apnea (OSA). ${ }^{7}$ The cardinal symptom of SDB
Correspondence: Pablo E Brockmann Department of Pediatric Cardiology and Pulmonology, Division of Pediatrics, School of Medicine, Pontificia Universidad Católica de Chile, Lira 85 5to piso, 8330074 Santiago, Chile

Tel +56223543767

Fax +56226384307

Email pbrockmann@med.puc.cl
Journal of Asthma and Allergy 2016:9 83-91

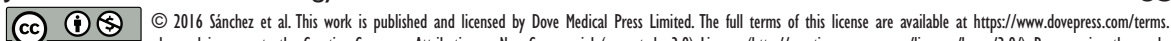
cc) you hereby accept the Terms. Non-commercial uses of the work are permitted without any further permisision from Dove Medical Press limited, provided the work is properly attributed. For

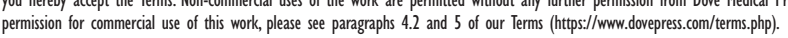

Dovepress

http://dx.doi.org/10.2147/JAA.S85624

83 
is habitual snoring (ie, snoring in more than three nights weekly). Similar to asthma, symptoms of SDB may remain unrecognized for a long time. ${ }^{8}$ Treatment of SDB, for example, adenotonsillectomy (AT), often resolves snoring and concomitant symptoms. However, a large multicenter study in asthmatic children ${ }^{9}$ showed that SDB may persist even after AT.

Furthermore, asthma and SDB may coexist, as they are both inflammatory diseases of the lower and upper airway tract, respectively. ${ }^{10}$ Similar symptoms during the night may also lead to confusion in clinical history. The similarities and parallel rise of prevalence of both diseases in the last decades arise the question that if there is a relationship between asthma and SDB. ${ }^{11}$

Therefore, we launched the present systematic review, in order to describe the relationship between asthma and SDB, especially regarding the impact of treatment and management of these diseases.

\section{Methods}

\section{Search and selection criteria}

We identified all published studies in MEDLINE, EMBASE, and LILACS (up to November 2015) database, using following keywords: "(asthma OR wheezing) AND (sleep) AND (obstructive sleep apnea OR sleep disordered breathing) AND (children OR child OR adolescent)". Studies published solely in abstract form were excluded because methods and results could not be fully analyzed. To be included, studies had to meet all the following criteria: case-control, cohort, or intervention studies that examined the relationship between asthma/wheezing and SDB/OSA in subjects aged $<18$ years of age; and all kinds of treatments were accepted (especially AT, considered the first-line treatment for SDB). No language restriction for the studies was applied. We excluded studies in which participants had any other chronic underlying disease such as craniofacial abnormalities, neurological disorders, dysmorphic genetic disorders or metabolic disorders, or other chronic respiratory illness different from asthma/wheezing. All references were managed by reference manager software (Mendeley ${ }^{\circledR}$ 1.14; Elsevier Inc, Philadelphia, PA, USA).

\section{Target conditions}

Childhood asthma was accepted as a clinical diagnosis (ie, "chronic inflammatory disease of the lower respiratory tract with recurrent or persistent wheezing"). ${ }^{3}$ Most of the studies usually diagnosed asthma by questionnaire. On the other hand, SDB was defined according to the International Classification of Sleep Disorders-third edition ${ }^{12}$ (ie, habitual snoring, upper airway resistance syndrome, and OSA). It was accepted that SDB diagnosis was made clinically or through questionnaire or polysomnography (PSG).

Our primary outcomes were 1) prevalence of asthma and SDB (using different tests for their diagnoses), 2) asthma as a risk factor for SDB and vice versa, and 3) the influence of their management.

\section{Data extraction and assessment of risk of bias}

Titles, abstracts, and citations were independently analyzed by two authors (TS and PEB). Based on the full-text form, all studies were evaluated for inclusion/exclusion criteria, type of intervention, population included, study design, and outcomes. After obtaining full reports about potentially relevant trials, eligibility was assessed. Disagreements were discussed and resolved by consensus.

\section{Results \\ Studies description}

In total, 1,020 (n) studies were identified. Among those, $32(\mathrm{~N})$ studies $^{9,10,13-42}$ met the inclusion criteria (Figure 1). The studies included a total of 143,343 children (51.3\% were males) of age (mean \pm standard deviation) $8.4 \pm 2.5$ years. Fourteen studies came from USA, 9,22,24,25,29,31,34-36,38-42 nine from Asia, ${ }^{13,14,18,20,28,30,32,33,37}$ seven from Europe, ${ }^{10,15-17,19,23,26}$

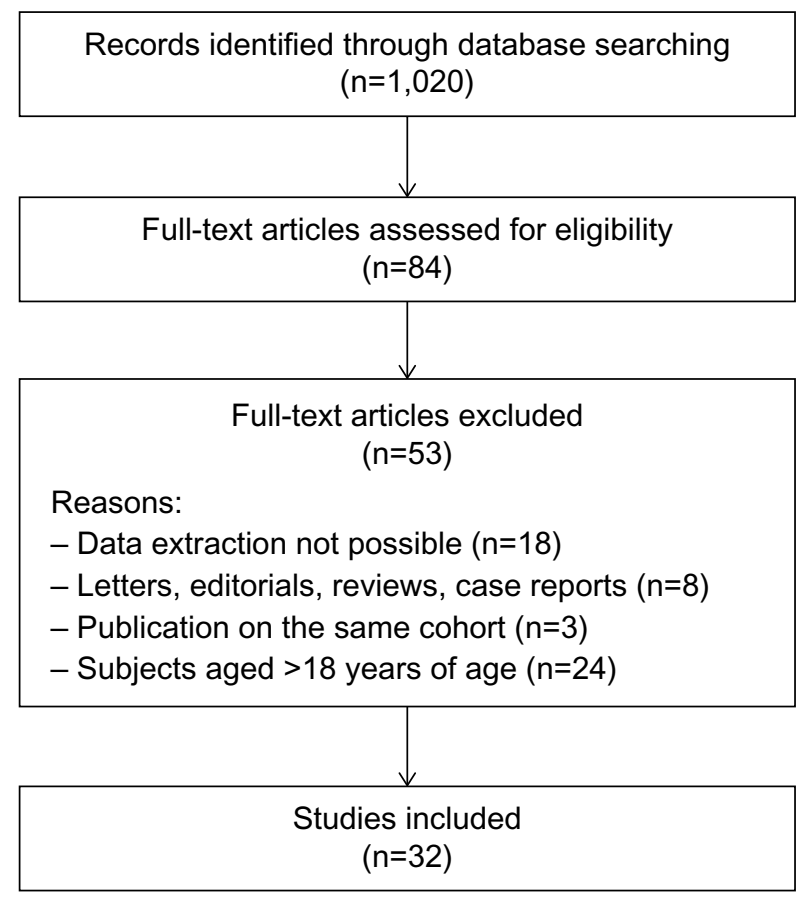

Figure I Study selection process of the included/excluded studies. 
and two from Oceania. ${ }^{21,27}$ Almost all studies diagnosed SDB using questionnaires (ie, the Pediatric Sleep Questionnaire [PSQ]), ${ }^{18,29,32,33}$ clinical history, ${ }^{10,13-17,19-23,26-28,35}$ or previous medical diagnosis. ${ }^{36,38,39,42}$ Eight studies performed PSG, ${ }^{9,24,30,31,34,37,40,41}$ and only one, a home cardiorespiratory polygraphy. ${ }^{25}$ On the other hand, the diagnosis of asthma was based on clinical history exclusively in 16 studies, $, 9,10,15,17,19,23-26,30-32,35,39,40,42$ previous medical asthma diagnosis in four studies,,$^{20,29,36,38}$ general questionnaires in six studies, ${ }^{14,15,17,18,21,33}$ and the International Study of Asthma and Allergies in Childhood ${ }^{43}$ questionnaire in six studies. ${ }^{13,16,22,27,28,34}$ Only five studies performed spirometry for assessing asthma. ${ }^{16,22,25,34,41}$

\section{Studies on association and/or risk of SDB in asthmatics}

Table 1 shows the studies that investigated the association between asthma and SDB. ${ }^{9,10,16,21,24,25,27-32,34,35,37}$ The aim of eleven studies was to describe the prevalence and risk factors of SDB, among which we were able to find data on asthma. ${ }^{13-15,17,18,20,22,26,33,40,41}$ Table 2 gives the result of them.

Overall, the studies showed that children with asthma/ wheeze were more likely to have a higher risk for habitual snoring and OSA than those without asthma. For example, a study in Belgian children ${ }^{28}$ reported that wheezing was related to an increased risk of snoring (odds ratio $[\mathrm{OR}]=2.8$, 95\% CI 1.1-2.6). A study on Austrian children ${ }^{27}$ showed a strong and significant association between SDB symptoms and wheeze/asthma, especially between snoring ( $\mathrm{OR}=5.4$, 95\% CI 3.6-8.1) and snorting (OR $=5.3,95 \%$ CI 2.6-10.8) with wheezing in the last 12 months. In another study, children with wheezing had a significantly higher prevalence of snoring, and more nocturnal awakenings than non-wheezing children (46\% vs $26 \%$ and $30 \%$ vs $20 \%$, respectively); after multiple logistic regression analysis, wheeze remained as a risk factor for difficulties falling asleep $(\mathrm{OR}=2.0,95 \% \mathrm{CI}$ 1.0-4.0), restless sleep ( $O R=5.0,95 \%$ CI 2.2-11.1), daytime sleepiness (OR $=3.8,95 \%$ CI 1.8-8.0), and tiredness (OR $=5.1,95 \%$ CI 2.2-12.1). ${ }^{16}$ Asthma was also associated with tonsillar hypertrophy. In a prospective cohort of 442 Greek children who consulted the emergency department (ED) and pulmonology clinic, history of wheezing was significantly associated with the presence of tonsillar hypertrophy and snoring ( $\mathrm{OR}=2.36,95 \%$ CI 1.46-3.79 and $\mathrm{OR}=1.88,95 \%$ CI 1.24-2.86, respectively). ${ }^{10}$ When questionnaires (eg, PSQ) were used, ${ }^{29}$ the prevalence of a positive test $(>0.33)$ was significantly higher in asthmatic children than in non-asthmatic children $(25.9 \%$ vs $10.6 \%$,
$P<0.001$, respectively; OR $=2.94,95 \%$ CI 1.82-4.75). Interestingly, the effect of asthma was "dose dependent", as children with more severe asthma had increased OR for snoring and a positive PSQ.

Studies using PSG to determine SDB showed similar results. A study in 50 African-American children ${ }^{34}$ concluded that poorly controlled asthma was associated with more severe OSA; a history of lifetime asthma increased the apnea-hypopnea index (AHI) by $8.8(P<0.005)$ in the PSG. A study ${ }^{24}$ that investigated parameters of sleep fragmentation by PSG concluded that asthmatic snorer's children had worse sleep quality as judged by indices of sleep fragmentation than those without asthma. Moreover, a study of OSA diagnosed by PSG in a sleep center in the $\mathrm{USA}^{31}$ reported that maximal \% $\mathrm{SpO}_{2}$ rapid-eye-movement (REM) desaturation, REM-obstructive AHI, and prevalence of REM-related OSA were significantly increased in asthmatic children with OSA compared to subjects with only OSA, showing that asthma is associated with REM-related breathing abnormalities in children with moderate-severe OSA. A cross-sectional study ${ }^{37}$ that investigated sleep quality by PSG in children aged 6-12 years found that asthmatics had significantly longer sleep latency and less slow-wave sleep compared with nonasthmatics; also, asthmatics (either with or without OSA) had significantly more leg movement than non-asthmatics. This study supports the hypothesis that nonobese asthmatic children, with or without OSA, may exhibit poor sleep quality as compared with nonobese non-asthmatic children. There is a known seasonal variability described in $\mathrm{SDB}^{44}$ In our studies, asthma and atopy did not explain this variation. Greenfeld et $\mathrm{al}^{30}$ in a review on 2,178 PSG of children and adolescents referred for suspected SDB, with a prevalence of asthma of $18 \%$, found that the mean obstructive AHI in the winter was significantly higher compared to the summer (9.1 \pm 9.6 vs $7.5 \pm 7.0, P=0.01$; Cohen $d=0.19)$, particularly in children younger than the age of 5 years $(10.2 \pm 10.5$ vs 7.9 $\pm 7.3, P=0.008$; Cohen $d=0.25)$, and asthma/atopy had no significant effect on seasonal variability.

In contrast to the studies described, only one study showed that a history of asthma decreased the likelihood of OSA. ${ }^{24}$ That was a retrospective review of patients referred to a sleep laboratory for an overnight PSG, and it compared the definition of OSA as an AHI $>2$ or $>5$. No significant differences in OSA prevalence or severity for asthmatics compared to non-asthmatics were found. The authors of that study explained these findings due to a possible referral bias; since parents of asthmatics would be more vigilant regarding night-time symptoms, they may have mistaken night noises 
Table I Association of asthma and SDB

\begin{tabular}{|c|c|c|c|c|c|c|c|c|}
\hline Author (year) & Country & $\mathbf{N}$ & Male & $\begin{array}{l}\text { Mean age } \\
\text { (years) }\end{array}$ & Asthma diagnosis & SDB diagnosis & $\begin{array}{l}\text { Prevalence of } \\
\text { asthma (\%) }\end{array}$ & $\begin{array}{l}\text { Prevalence } \\
\text { of SDB (\%) }\end{array}$ \\
\hline Lu et al $(2003)^{21}$ & Australia & 974 & 516 & Not given & Questionnaire & $\begin{array}{l}\text { Snoring for }+4 \text { nights/ } \\
\text { week }\end{array}$ & 28 & 10.5 \\
\hline $\begin{array}{l}\text { Valery et al } \\
(2004)^{27}\end{array}$ & Australia & $\mathrm{I}, 650$ & Not given & 8.5 & ISAAC questions & Snoring & 15.6 & 14.2 \\
\hline $\begin{array}{l}\text { Sulit et al } \\
(2005)^{25}\end{array}$ & USA & 788 & 393 & 9.5 & $\begin{array}{l}\text { History or } \\
\text { spirometry }\end{array}$ & $\begin{array}{l}\text { Portable polygraphy } \\
\mathrm{AHI}>5\end{array}$ & 13.3 & 20.1 \\
\hline $\begin{array}{l}\text { Desager et al } \\
(2005)^{16}\end{array}$ & Belgium & 1,234 & Not given & 9.6 & $\begin{array}{l}\text { ISAAC questions, } \\
\text { spirometry }\end{array}$ & Snoring & 8.8 & 28 \\
\hline $\begin{array}{l}\text { Verhulst et al } \\
(2007)^{28}\end{array}$ & Sri Lanka & 652 & 432 & 8.4 & ISAAC questions & Snoring & 14 & 32.6 \\
\hline $\begin{array}{l}\text { Ramagopal et al } \\
(2008)^{24}\end{array}$ & USA & 236 & 147 & 7.2 & History & PSG AHI >2 & 31.4 & $4 I .1$ \\
\hline $\begin{array}{l}\text { Ramagopal et al } \\
(2009)^{34}\end{array}$ & USA & 50 & 32 & 9.3 & $\begin{array}{l}\text { ISAAC questions + } \\
\text { spirometry }\end{array}$ & PSG AHI >2 & 44 & 100 \\
\hline $\begin{array}{l}\text { Kaditis et al } \\
(2010)^{10}\end{array}$ & Greece & 442 & 241 & 7.6 & History & Habitual snoring & 47.5 & 28.5 \\
\hline $\begin{array}{l}\text { Bhattacharjee } \\
\text { et al }(2010)^{9}\end{array}$ & USA & 578 & 355 & 6.9 & History & PSG & 29.6 & 100 \\
\hline $\begin{array}{l}\text { Ross et al } \\
(2012)^{35}\end{array}$ & USA & 108 & 73 & 9.1 & History & $\begin{array}{l}\text { Snoring for }+3 \text { nights/ } \\
\text { week }+\geq 3 \text { desaturations } \\
>3 \% / \text { hour }\end{array}$ & 100 & 29.6 \\
\hline $\begin{array}{l}\text { Greenfeld et al } \\
(2013)^{30}\end{array}$ & Israel & 2,178 & I,4I5 & 4.9 & History & PSG OAHI >I & 18 & 100 \\
\hline $\begin{array}{l}\text { Gutierrez et al } \\
(2013)^{31}\end{array}$ & USA & $|4|$ & 85 & 6.1 & History & PSG OAHI $>1.5$ & 43.9 & 100 \\
\hline $\begin{array}{l}\text { Goldstein et al } \\
(2015)^{29}\end{array}$ & USA & 529 & 298 & 5.8 & Previous diagnosis & $\mathrm{PSQ}>0.33$ & 50 & 18.2 \\
\hline $\begin{array}{l}\text { Teng et al } \\
(20 \mid 4)^{37}\end{array}$ & Taiwan & 102 & 56 & 9.4 & $\begin{array}{l}\text { History }+ \\
\text { methacholine test }\end{array}$ & PSG AHI >5 & 50 & 50 \\
\hline Li et al $(2015)^{32}$ & $\begin{array}{l}\text { People's Republic } \\
\text { of China }\end{array}$ & 22,478 & 10,227 & 9 & History & $\mathrm{CSHQ}$ & 3.5 & 12 \\
\hline Mean prevalence & & & & & & & 33.2 & 41.8 \\
\hline
\end{tabular}

Abbreviations: SDB, sleep-disordered breathing; ISAAC, International Study on Asthma and Allergies in Childhood; AHI, apnea-hypopnea index; PSG, polysomnography; OAHI, obstructive apnea-hypopnea index; PSQ, Pediatric Sleep Questionnaire; CSHQ, Children's Sleep Habits Questionnaire.

(asthma symptoms and noisy breathing) for snoring, having an "over"-report of night symptoms.

\section{Studies on association and/or risk of asthma in children with SDB}

Children with SDB were more likely to develop asthma/ wheeze than those without asthma/wheeze. Lu et $\mathrm{al}^{21}$ reported that $42.2 \%$ of children who snored had asthma (OR $=2.03$, 95\% CI 1.34-3.10). There was also a highly significant association between snoring and nocturnal cough $(\mathrm{OR}=3.68,95 \%$ CI 2.41-5.63). In that study, nocturnal cough was strongly associated with asthma; in the asthmatic group, the prevalence of nocturnal cough was significantly higher among children who snored vs children who did not snore (86.1\% vs $52.6 \%$, respectively, $P=0.001$; OR $=5.56,95 \%$ CI 2.26-13.67). Sulit et $\mathrm{al}^{25}$ in a US community-based cohort study of 788 participants (aged 8-11 years) found that children with SDB had nearly twice the odds of wheeze compared with those without SDB (OR =1.89, 95\% CI 1.26-2.85). Recently, a large Chinese epidemiological study ${ }^{32}(n=20,672$ children, mean age $9.0 \pm 1.61$ years) concluded that habitual snoring and OSA remained a statistically significant predictor of asthma $(\mathrm{OR}=1.28,95 \% \mathrm{CI} 1.01-1.62$ and $\mathrm{OR}=1.92,95 \%$ CI 1.34-2.76, respectively). In a prospective study on 108 asthmatic patients (mean age $9.1 \pm 3.4$ years), children with SDB had more than three times the risk for having severe asthma at follow-up (OR $=3.62,95 \%$ CI 1.26-10.4). ${ }^{35}$

Only three studies that analyzed risk factors for asthma development investigated SDB. ${ }^{19,23,36}$ Those results are given in the following. In the study of Hoskyns et al, ${ }^{19}$ the relationship between night cough and other indices of asthma severity was studied in 21 children with clinically stable asthma and 
Table 2 Prevalence of SDB and asthma as a risk factor

\begin{tabular}{|c|c|c|c|c|c|c|c|c|}
\hline Author (year) & Country & $\mathbf{N}$ & Male & $\begin{array}{l}\text { Mean } \\
\text { age } \\
\text { (years) }\end{array}$ & Asthma diagnosis & SDB diagnosis & $\begin{array}{l}\text { SDB } \\
\text { prevalence (\%) - } \\
\text { asthma vs controls }\end{array}$ & OR $(95 \% \mathrm{Cl})$ \\
\hline $\begin{array}{l}\text { Redline et al } \\
(1999)^{41}\end{array}$ & USA & 399 & 194 & 10.9 & History + spirometry & PSG AHI $>10$ & II.8 vs 28 & $3.83(1.39-10.55)$ \\
\hline $\begin{array}{l}\text { Corbo et al } \\
(2001)^{15}\end{array}$ & Italy & 2,209 & 722 & 12.5 & $\begin{array}{l}\text { Previous diagnosis or } \\
\text { questionnaire }\end{array}$ & Snoring "often" & I2.2 vs 7.6 & $1.79(0.97-3.33)$ \\
\hline Chng et al $(2004)^{14}$ & Singapore & 11,114 & 5,212 & 5.8 & Questionnaire & $\begin{array}{l}\text { Snoring for }>3 \text { nights/ } \\
\text { week }\end{array}$ & 8.6 vs 5.1 & $1.83(1.50-2.24)$ \\
\hline $\begin{array}{l}\text { Urschitz } \\
(2004)^{26}\end{array}$ & Germany & $\mathrm{I}, \mathrm{I} 44$ & 585 & 9.6 & History & $\begin{array}{l}\text { "Frequently" or "always" } \\
\text { snoring }\end{array}$ & 7.1 vs 9.8 & $0.68(0.24-1.94)$ \\
\hline Ersu et al $(2004)^{17}$ & Turkey & 2,147 & $\mathrm{I}, 074$ & 8.5 & $\begin{array}{l}\text { History, } \\
\text { questionnaire }\end{array}$ & $\begin{array}{l}\text { "Often" or "always" } \\
\text { snoring }\end{array}$ & 9.1 vs 7.6 & $1.25(0.75-2.09)$ \\
\hline Bidad et al $(2006)^{13}$ & Iran & 2,900 & 1,200 & 14 & ISAAC questions & $\begin{array}{l}\text { Snoring for } \geq 3 \text { nights/ } \\
\text { week }\end{array}$ & I0.7 vs 7.1 & $1.64(1.05-2.58)$ \\
\hline $\begin{array}{l}\text { Marshall et al } \\
(2007)^{22}\end{array}$ & USA & 219 & 107 & 5 & $\begin{array}{l}\text { ISAAC questions, } \\
\text { spirometry }\end{array}$ & $\begin{array}{l}\text { Snoring for } \geq 3 \text { nights/ } \\
\text { week }\end{array}$ & 29.1 vs 16.9 & $2.71(1.42-5.16)$ \\
\hline Li et al $(2010)^{20}$ & $\begin{array}{l}\text { People's } \\
\text { Republic of } \\
\text { China }\end{array}$ & 20,152 & 9,890 & 9 & Previous diagnosis & $\begin{array}{l}\text { "Frequently" or "almost } \\
\text { always" snoring }\end{array}$ & 17.8 vs 10.5 & $2.09(1.72-2.54)$ \\
\hline $\begin{array}{l}\text { Kheirandish-Gozal } \\
\text { et al }(20 \mathrm{II})^{40}\end{array}$ & USA & 92 & 49 & 6.6 & History & PSG AHI 5/hour TST & 63.0 vs 4.0 & $40.9(|2.9-| 44 . \mid)$ \\
\hline Fadzil et al $(2012)^{18}$ & Malaysia & 550 & 285 & 8.5 & Questionnaire & PSQ $>0.33$ & 29.2 vs 13.5 & $2.62(1.34-5.15)$ \\
\hline $\mathrm{Ng}$ et al $(2014)^{33}$ & $\begin{array}{l}\text { People's } \\
\text { Republic of } \\
\text { China }\end{array}$ & 2,005 & 1,173 & 15.3 & Questionnaire & $\begin{array}{l}\text { Snoring for } \geq 6 \text { nights/ } \\
\text { week }\end{array}$ & 17.9 vs 9.7 & $2.18(I .25-3.7 I)$ \\
\hline
\end{tabular}

Abbreviations: SDB, sleep-disordered breathing; OR, odds ratio; Cl, confidence interval; PSG, polysomnography; AHI, apnea-hypopnea index; ISAAC, International Study on Asthma and Allergies in Childhood; TST, total sleep time; PSQ, Pediatric Sleep Questionnaire.

persistent night cough; there was an association of SDB with asthma. A study aimed to develop an asthma prediction tool for preschoolers with wheeze or cough; snoring resulted as a predictive factor for asthma 5 years later $(77.4 \%$ vs $69.6 \%$, asthma vs no asthma, $P=0.006) .{ }^{23}$ Finally, a retrospective cohort study ${ }^{36}$ of asthmatic children $(n=25,900)$ who required hospitalization showed a higher risk of hospital length of stay $>2$ days ( $\mathrm{OR}=2.3,95 \%$ CI 1.8-2.9) for those with previous diagnosis of OSA (1.4\% of the group) than those without OSA. The authors of that study suggested that children with OSA and asthma experience a higher severity of nocturnal hypoxemia and hypoventilation; therefore, it may possibly take longer time to return to an acceptable respiratory status after an asthma crisis.

\section{Studies on therapy}

Table 3 shows the results from the studies analyzing treatment's impact. No studies of asthma treatment that influence SDB were found. On the other hand, five studies investigated the effect of AT in asthma control. ${ }^{9,38-40,42}$ Bhattacharjee et $\mathrm{al}^{38}$ conducted a large study of asthmatic children $(n=13,506)$ who underwent AT, and the surgical procedure was associated with significant reductions in acute asthmatic exacerbations
(30.2\%, 95\% CI 25.6\%-34.3\%; $P<0.0001)$, acute status asthmaticus $(37.9 \%$, 95\% CI 29.2\%-45.6\%; $P<0.0001)$, asthma-related ED visits $(25.6 \%$, 95\% CI 16.9\%-33.3\%; $P<0.0001)$, and asthma-related hospitalizations $(35.8 \%$, 95\% CI 19.6\%-48.7\%; $P=0.02$ ). Moreover, AT was associated with significant reductions in most asthma prescription refills, including bronchodilators, inhaled corticosteroids, leukotriene receptor antagonists (LTRAs), and systemic corticosteroids. Kheirandish-Gozal et $\mathrm{al}^{40}$ conducted a prospective study on 92 poorly controlled asthma children (aged 3-10 years) with a mean frequency of acute asthmatic exacerbations of $3.4 \pm 0.4 /$ year. Overnight PSG revealed the presence of OSA (AHI $>5 /$ hour of total sleep time) in $63.0 \%$ of patients $(\mathrm{OR}=40.9,95 \% \mathrm{CI} 12.9-144.1)$ compared to the maximal estimated prevalence of OSA in a non-asthmatic population. From this group, information at 1-year followup was available for 35 asthmatics with OSA after AT, and for 24 without OSA. The annual frequency of acute asthmatic exacerbations in the post-AT subgroup significantly decreased (from $4.1 \pm 1.3$ to $1.8 \pm 1.4$ /year, $P<0.0001$ ), with no changes in the non-OSA group. Similar favorable improvement occurred after AT in the frequency of $\beta$-agonist rescue use or in asthma symptom scores. Busino et $\mathrm{al}^{39}$ reviewed 
Table 3 Studies on impact of treatment of SDB and asthma

\begin{tabular}{|c|c|c|c|c|c|c|c|c|}
\hline Author (year) & Country & $\mathbf{N}$ & Male & $\begin{array}{l}\text { Mean } \\
\text { age } \\
\text { (years) }\end{array}$ & $\begin{array}{l}\text { Asthma } \\
\text { diagnosis }\end{array}$ & $\begin{array}{l}\text { SDB } \\
\text { diagnosis }\end{array}$ & Type of study & Main results \\
\hline $\begin{array}{l}\text { Bhattacharjee } \\
\text { et al }(2010)^{9}\end{array}$ & USA & 578 & 355 & 6.9 & History & PSG & $\begin{array}{l}\text { Retrospective study: } \\
578 \text { children with OSA } \\
\text { undergoing AT studied } \\
\text { with PSG preoperatively } \\
\text { and postoperatively }\end{array}$ & $\begin{array}{l}\text { AT resulted in a significant AHI } \\
\text { reduction from } 18.2 \pm 2 I .4 \text { to } \\
4.1 \pm 6.4 / \text { hour total sleep time. } \\
27.2 \% \text { had complete resolution } \\
\text { of OSA; asthma was a modest } \\
\text { contributing factor for post-AT } \\
\text { AHI }\end{array}$ \\
\hline $\begin{array}{l}\text { Bhattacharjee } \\
\text { et al }(2014)^{38}\end{array}$ & USA & 40,518 & 22,320 & 7.7 & ICD-9-CM & ICD-9-CM & $\begin{array}{l}\text { Retrospective study: } \\
\text { I3,506 children with } \\
\text { asthma with AT } \\
\text { compared to } 27,012 \\
\text { matched children with } \\
\text { asthma without AT }\end{array}$ & $\begin{array}{l}\text { AT associated with reductions } \\
\text { in AAE (30.2\%), ASA (37.9\%), } \\
\text { ARERs ( } 25.6 \%), \text { ARHs }(35.8 \%) \text {, } \\
\text { bronchodilators ( } 16.7 \%) \text {, } \\
\text { inhaled corticosteroids } \\
\text { (2I.5\%), leukotriene receptor } \\
\text { antagonists (I3.4\%), and systemic } \\
\text { corticosteroids ( } 23.7 \%)\end{array}$ \\
\hline $\begin{array}{l}\text { Busino et al } \\
(2010)^{39}\end{array}$ & USA & 465 & 263 & 5.9 & $\begin{array}{l}\text { Clinical } \\
\text { history }\end{array}$ & $\begin{array}{l}\text { Previous } \\
\text { diagnosis }\end{array}$ & $\begin{array}{l}\text { Retrospective study: } \\
465 \text { children with AT, } \\
16.6 \% \text { asthmatics }\end{array}$ & $\begin{array}{l}\text { AT associated with reductions } \\
\text { of asthma therapies (eg, } \\
\text { corticosteroids) and } \\
\text { improvements in ACT scores }\end{array}$ \\
\hline $\begin{array}{l}\text { Kheirandish-Gozal } \\
\text { et al }(20 \mathrm{II})^{40}\end{array}$ & USA & 92 & 49 & 6.6 & $\begin{array}{l}\text { Clinical } \\
\text { history }\end{array}$ & $\begin{array}{l}\text { PSG AHI } \\
>5 / \text { hour TST }\end{array}$ & $\begin{array}{l}\text { Prospective study: } \\
92 \text { children with } \\
\text { poorly controlled } \\
\text { asthma, } 63 \% \text { with } \\
\text { OSA and AT }\end{array}$ & $\begin{array}{l}\text { AT associated with reduction in } \\
\text { AAE ( } 4 . I \pm I .3 \text { to } I .8 \pm I .4 / \text { year }) \\
\beta \text {-agonist rescue use }(4.3 \pm I .8 \text { to } \\
2.1 \pm I .5 / \text { week), and ACT scores } \\
(3.1 \pm I .9 \text { to } I .9 \pm I .7)\end{array}$ \\
\hline $\begin{array}{l}\text { Levin et al } \\
(2014)^{42}\end{array}$ & USA & 130 & 55 & 6.1 & $\begin{array}{l}\text { Clinical } \\
\text { history }\end{array}$ & $\begin{array}{l}\text { Previous } \\
\text { diagnosis }\end{array}$ & $\begin{array}{l}\text { Longitudinal } \\
\text { observational study: } \\
\text { I } 30 \text { children with AT } \\
\text { ( } 66 \text { asthmatics and } \\
64 \text { controls) }\end{array}$ & $\begin{array}{l}\text { AT associated in children with } \\
\text { asthma with improvement in ACT } \\
\text { scores (22-25) and decrease } \\
\text { in emergency department/ } \\
\text { urgent care visits ( } 1.88-0.4) \text {, } \\
\text { oral corticosteroid courses } \\
\text { (I.II-0.2I), missed school days } \\
\text { due to asthma (3.86-2.0), total } \\
\text { missed parental work days due to } \\
\text { illness }(2.79-I .13) \text {, and circulating } \\
\text { chitinase activity }(0.4 \text { nmol/L/mL/h) }\end{array}$ \\
\hline
\end{tabular}

Abbreviations: SDB, sleep-disordered breathing; PSG, polysomnography; OSA, obstructive sleep apnea; AT, adenotonsillectomy; AHI, apnea-hypopnea index; ICD-9-CM, International Classification of Diseases, Ninth Revision, Clinical Modification; AAE, acute asthmatic exacerbation; ASA, acute status asthmaticus; ARERs, asthma-related emergency room visits; ARHs, asthma-related hospitalizations; ACT, asthma control test; TST total sleep time.

retrospectively 560 children who underwent AT; 16,6\% were asthmatics, $97.8 \%$ of this group underwent AT for OSA. AT was associated with significant reductions in asthma therapies, including corticosteroids, and with improvements in asthma control test scores.

\section{Discussion}

In this systematic review of 32 studies, we found a mean prevalence of asthma of $33.2 \%$, and of SDB $41.8 \%$. Asthma is estimated to affect 7.1 million US children under the age of 18 years. ${ }^{1}$ The prevalence of asthma in children varies through different countries. In the studies we reviewed, the asthma prevalence ranged from $8.8 \%$ in Belgium ${ }^{16}$ to $28 \%$ in Australia. ${ }^{21}$
On the other hand, the prevalence of snoring is estimated to be $3.2 \%-12.1 \%$, and the prevalence of OSA ranges from $0.7 \%$ to $10.3 \% .{ }^{45}$ When parents were asked about habitual snoring (usually three or four times per week), the prevalence reported in the studies of this systematic review was $6 \%$ in a group of Singapore children, ${ }^{14} 7 \%$ in Turkey, ${ }^{17} 10.1 \%$ in Germany, ${ }^{26} 12 \%$ in the People's Republic of China, ${ }^{20,21,32,33}$ $14.6 \%$ in Australia, ${ }^{22}$ and $28 \%$ in Belgium. ${ }^{16}$ When standardized questionnaires were used (eg, the PSQ), the prevalence of SDB symptoms was $14.9 \%$ in Malaysia. ${ }^{18}$ However, PSG is known to be the gold standard for SDB but has important limitations due to availability and cost. This may explain the reason why only a few studies in our systematic review used it for SDB and OSA diagnosis. Redline et $\mathrm{l}^{41}$ reported the 
prevalence of SDB in a general population of children in the USA to be $1.6 \%$ and $10.3 \%$ by using a PSG diagnostic criteria of AHI $>10$ and 5 , respectively.

In order to discuss the current evidence of an association between SDB/OSA and asthma, it is important to mention the definitions of sleep-related breathing disorders. Childhood SDB is a spectrum of abnormal breathing patterns during sleep that ranges from primary snoring to OSA. OSA in children is an SDB characterized by prolonged partial upper airway obstruction and/or intermittent complete obstruction that affects normal ventilation during sleep. ${ }^{46}$ OSA is considered the most severe disease within the spectrum of SDB. It is associated with symptoms including habitual snoring, sleep difficulties, and daytime neurobehavioral problems and has the potential to result in serious long-term consequences, such as cognitive deficits, academic failure, cardiovascular complications, and metabolic syndrome.

There is a growing body of evidence of an association between SDB and asthma, supported by most of the studies described in our review. Our previous systematic review on prevalence of asthma and SDB including 17 studies involving 45,155 children found that children with asthma had a significantly higher risk of $\mathrm{SDB}(\mathrm{OR}=1.9,95 \% \mathrm{CI} 1.2-2.2) .{ }^{47}$ However, the relationship between asthma and SDB appears bidirectional. SDB, especially OSA, may exacerbate asthma by altering oropharyngeal reflexes and increasing negative intrathoracic pressure, increasing cholinergic tone, and promoting bronchoconstriction. ${ }^{14}$ Studies like the one by Pescatore et al reinforce that SDB may even predict asthma development. ${ }^{23}$ In addition, a large retrospective cohort showed that SDB may even prolong the recovery of children after hospitalization due to asthma. ${ }^{36}$

On the other hand, we found many studies showing that asthma may exacerbate SDB disrupting sleep, resulting in sleep deprivation and increasing the frequency of apneas in snorers. ${ }^{14}$ Also, poorly controlled asthma might accentuate the hypoxemia in SDB and vice versa; intermittent nocturnal hypoxemia in children with OSA could initiate and maintain upper and lower airway inflammation. ${ }^{48,49}$

Therefore, this bidirectional association may be explained due to common risk factors that promote airway inflammation, sharing a common pathogenetic pathway. This is referred as the "one-airway" hypothesis, suggesting that upper airway inflammation and intermittent hypoxia from obstruction may influence the expression and severity of disease of the lower respiratory tract. ${ }^{50,51}$ Lower and upper airway inflammation is related to atopy and incremented cysteinyl leukotriene activity, and can lead to decreased lower airway caliber and increased nasal resistance and pharyngeal collapsibility, ${ }^{52-54}$ predisposing to wheeze and snore during sleep. Also, adenotonsillar hypertrophy increases upper airway resistance and is the first cause of SDB in children. It seems that asthma is associated with tonsillar hypertrophy, ${ }^{10}$ and children with history of wheezing have larger tonsils than subjects without wheezing. Hypertrophic tonsils could mediate at least in part the known association between asthma and obstructive SDB in childhood. This is reinforced by two studies, ${ }^{55,56}$ demonstrating that increased cysteinyl leukotrienes activity is present in tonsils excised from children with OSA, seeming to promote tonsillar cell proliferation.

In addition to what we already knew concerning the possible relationship of asthma and $\mathrm{SDB},{ }^{49}$ we aimed to analyze in the present systematic review how treatment impacts on both diseases. We found several studies addressing how SDB treatment impacts on asthma. However, no studies were found so far that compared how asthma treatment impacts on SDB.

The first-line treatment for OSA in children is AT (if the patient has demonstrated adenotonsillar hypertrophy and does not have contraindications to surgery). ${ }^{15,46}$ In the past years, there has been increasing interest in studying the effect of AT, as first-line SDB/OSA treatment, and improvement of childhood asthma. ${ }^{38-40}$ Kheirandish-Gozal et $\mathrm{al}^{40}$ demonstrated that the annual frequency of acute asthmatic exacerbations in children post-AT decreased significantly compared to those without AT. Based on this interesting study, one may hypothesize that upper airway inflammatory processes may play a role in lower airway inflammation and asthma, and conversely, lower airway inflammatory disease may promote adenotonsillar proliferation, and therefore increase the propensity for OSA. ${ }^{40}$ Therefore, treatment of OSA may benefit control of asthma. In a study of Bhattacharjee et $\mathrm{al}^{38}$ on 13,506 children with asthma, only $6.2 \%$ of those who underwent AT and $0.6 \%$ of those who did not undergo the surgical procedure had some form of evaluation for SDB as determined by searching for specific sleep diagnostic testing. This finding shows that most patients are operated without having a sleep diagnosis, even if they are scheduled for a surgical procedure. Considering that asthmatics might have a higher prevalence and severity of OSA, a formal sleep study should be considered case by case, especially before surgical procedures. In another multicenter study by Bhattacharjee et $\mathrm{al}^{9}$ ( $\mathrm{n}=578$ children), the presence of asthma was a significant factor for persisting with OSA after AT, and the study underlined the importance of a post-AT PSG in children with asthma undergoing AT. A longitudinal observational study ${ }^{42}$ on 130 children (aged 2-18 years), both with and without asthma, undergoing AT showed that asthma control test scores and chitinase activity 
in the circulation (biomarkers of airway inflammation, such as upper airway and asthmatic disease) measured at time of surgery and at 6-month follow-up had a significant improvement. A significant improvement in asthma control test scores after 6 months and decrease in several asthma-related outcomes (eg, rate of ED visits, oral corticosteroid courses, missed school days due to asthma, and total missed parental work days) and in circulating chitinase activity (median decrease $0.4 \mathrm{nmol} / \mathrm{L} /$ $\mathrm{mL} / \mathrm{h}, P<0.01)$ suggest that AT also may modulate airway inflammation in asthma. These studies support the idea that detection and treatment of adenotonsillar tissue hypertrophy may serve as an important strategy for improving asthma control. However, randomized controlled studies are needed to confirm this.

There are certainly other treatment for OSA (ie, nasal corticosteroids sprays ${ }^{57,58}$ and LTRAs). ${ }^{59}$ Dental devices or oral appliance therapy, surgical procedures, and continuous positive airway pressure may be considered as second-line treatment. Most of them have specific indications for patients with specific chronic diseases (eg, neuromuscular disorders). We did not find eligible studies of these treatments in patients with asthma and SDB.

The present study, as usual in this kind of systematic reviews, has limitations that need to be addressed. We made the highest effort in finding most available studies on the topic. However, there are some interesting studies that might have escaped our search strategy. Prevalence of asthma and SDB was originally calculated only in some studies; we recalculated it from the data of several other included studies. Hence, this may have biased this outcome, as some studies were not intended as epidemiologic studies for prevalence estimation. In most included studies, asthma and SDB were among a long list of factors analyzed, but only few studies aimed to analyze specifically the relationship between them. Hence, a data extraction bias is also possible. Future studies specifically designed for demonstrating the bidirectional relationship between both diseases may help to confirm our results. As mentioned earlier, only studies that analyzed AT as treatment for SDB were found. Therefore, we do not know if other therapeutic options for SDB, for example, nasal corticosteroids, LTRAs, or maxillary interventions, may have some influence on asthma.

\section{Conclusion}

The present systematic review shows that asthma and SDB are both very frequent conditions in childhood, and may have a bidirectional relationship. Treatment of SDB seems to impact positively on the clinical evolution of asthma in children. It is yet to be proven whether or not optimizing asthma control could prevent consequences of SDB.

\section{Disclosure}

The authors report no conflicts of interest in this work.

\section{References}

1. Akinbami LJ, Moorman JE, Bailey C, et al. Trends in asthma prevalence, health care use, and mortality in the United States, 2001-2010. NCHS Data Brief. 2012;(94):1-8.

2. Castro-Rodriguez JA, Garcia-Marcos L. Wheezing and asthma in childhood: an epidemiology approach. Allergol Immunopathol (Madr). 2008;36(5):280-290.

3. Papadopoulos NG, Arakawa $\mathrm{H}$, Carlsen $\mathrm{KH}$, et al. International consensus on (ICON) pediatric asthma. Allergy. 2012;67(8): 976-997.

4. Janssens T, Harver A. Effects of symptom perception interventions on trigger identification and quality of life in children with asthma. Pulm Med. 2015;2015:825137.

5. Asher I, Pearce N. Global burden of asthma among children. Int JTuberc Lung Dis. 2014;18(11):1269-1278.

6. Lumeng JC, Chervin RD. Epidemiology of pediatric obstructive sleep apnea. Proc Am Thorac Soc. 2008;5(2):242-252.

7. Marcus CL. Sleep-disordered breathing in children. Am J Respir Crit Care Med. 2001;164(1):16-30.

8. Montgomery-Downs HE, O'Brien LM, Holbrook CR, Gozal D. Snoring and sleep-disordered breathing in young children: subjective and objective correlates. Sleep. 2004;27(1):87-94.

9. Bhattacharjee R, Kheirandish-Gozal L, Spruyt K, et al. Adenotonsillectomy outcomes in treatment of obstructive sleep apnea in children: a multicenter retrospective study. Am J Respir Crit Care Med. 2010;182(5):676-683.

10. Kaditis AG, Kalampouka E, Hatzinikolaou S, et al. Associations of tonsillar hypertrophy and snoring with history of wheezing in childhood. Pediatr Pulmonol. 2010;45(3):275-280.

11. Teodorescu M. Predictors of habitual snoring and obstructive sleep apnea risk in patients with asthma. Chest J. 2009;135(5):1125.

12. Sateia MJ. International classification of sleep disorders-third edition: highlights and modifications. Chest. 2014;146(5):1387-1394.

13. Bidad K, Anari S, Aghamohamadi A, Gholami N, Zadhush S, Moaieri H. Prevalence and correlates of snoring in adolescents. Iran J Allergy Asthma Immunol. 2006;5(3):127-132.

14. Chng SY, Goh DYT, Wang XS, Tan TN, Ong NBH. Snoring and atopic disease: a strong association. Pediatr Pulmonol. 2004;38(3): 210-216.

15. Corbo GM, Forastiere F, Agabiti N, et al. Snoring in 9- to 15-year-old children: risk factors and clinical relevance. Pediatrics. 2001;108(5): 1149-1156.

16. Desager KN, Nelen V, Weyler JJJ, De Backer WA. Sleep disturbance and daytime symptoms in wheezing school-aged children. J Sleep Res. 2005;14(1):77-82.

17. Ersu R, Arman AR, Save D, et al. Prevalence of snoring and symptoms of sleep-disordered breathing in primary school children in Itanbul. Chest. 2004;126(1):19-24.

18. Fadzil A, Jamalludin A, Norrashidah A, et al. Prevalence of sleep disordered breathing symptoms among Malay school children in a primary school in Malaysia. Med J Malaysia. 2012;67(2):181-185.

19. Hoskyns EW, Beardsmore CS, Simpson H. Chronic night cough and asthma severity in children with stable asthma. Eur J Pediatr. 1995;154(4):320-325.

20. Li S, Jin X, Yan C, Wu S, Jiang F, Shen X. Habitual snoring in schoolaged children: environmental and biological predictors. Respir Res. 2010;11(1):144.

21. Lu LR, Peat JK, Sullivan CE. Snoring in preschool children: prevalence and association with nocturnal cough and asthma. Chest. 2003;124(2):587-593.

22. Marshall NS, Almqvist C, Grunstein RR, Marks GB. Predictors for snoring in children with rhinitis at age 5. Pediatr Pulmonol. 2007;42(7):584-591. 
23. Pescatore AM, Dogaru CM, Duembgen L, et al. A simple asthma prediction tool for preschool children with wheeze or cough. J Allergy Clin Immunol. 2014;133(1):111.e13-118.e13.

24. Ramagopal M, Scharf SM, Roberts DW, Blaisdell CJ. Obstructive sleep apnea and history of asthma in snoring children. Sleep Breath. 2008;12(4):381-392.

25. Sulit LG, Storfer-Isser A, Rosen CL, Kirchner HL, Redline S. Associations of obesity, sleep-disordered breathing, and wheezing in children. Am J Respir Crit Care Med. 2005;171(6):659-664.

26. Urschitz MS. Risk factors and natural history of habitual snoring. Chest. 2004;126(3):790.

27. Valery PC, Masters IB, Chang AB. Snoring and its association with asthma in Indigenous children living in the Torres Strait and Northern Peninsula Area. J Paediatr Child Health. 2004;40(January):461-465.

28. Verhulst SL, Vekemans K, Ho E, et al. Is wheezing associated with decreased sleep quality in Sri Lankan children? A questionnaire study. Pediatr Pulmonol. 2007;42(7):579-583.

29. Goldstein NA, Aronin C, Kantrowitz B, et al. The prevalence of sleepdisordered breathing in children with asthma and its behavioral effects. Pediatr Pulmonol. 2015;50(11):1128-1136.

30. Greenfeld M, Sivan Y, Tauman R. The effect of seasonality on sleep-disordered breathing severity in children. Sleep Med. 2013; 14(10):991-994.

31. Gutierrez MJ, Zhu J, Rodriguez-Martinez CE, Nino CL, Nino G. Nocturnal phenotypical features of obstructive sleep apnea (OSA) in asthmatic children. Pediatr Pulmonol. 2013;48:592-600.

32. Li L, Xu Z, Jin X, et al. Sleep-disordered breathing and asthma: evidence from a large multicentric epidemiological study in China. Respir Res 2015;16(1):56.

33. $\mathrm{Ng} \mathrm{DK}$, Chan $\mathrm{C}, \mathrm{Ng}$ EP. Natural history of snoring in Hong Kong adolescents. J Paediatr Child Health. 2014;50(8):596-604.

34. Ramagopal M, Mehta A, Roberts DW, et al. Asthma as a predictor of obstructive sleep apnea in urban African-American children. JAsthma. 2009;46(9):895-899.

35. Ross KR, Storfer-Isser A, Hart MA, et al. Sleep-disordered breathing is associated with asthma severity in children. J Pediatr. 2012;160(5):736-742.

36. Shanley L, Lin H, Flores G. Factors associated with length of stay for pediatric asthma hospitalizations. J Asthma. 2015;52(5):471-477.

37. Teng YK, Chiang LC, Lue KH, et al. Poor sleep quality measured by polysomnography in non-obese asthmatic children with or without moderate to severe obstructive sleep apnea. Sleep Med. 2014;15(9):1062-1067.

38. Bhattacharjee R, Choi BH, Gozal D, Mokhlesi B. Association of adenotonsillectomy with asthma outcomes in children: a longitudinal database analysis. PLoS Med. 2014;11(11):e1001753.

39. Busino RS, Quraishi H, Aguila H, Montalvo E, Connelly P. The impact of adenotonsillectomy on asthma in children. Laryngoscope. 2010;120(Suppl 4):2007.

40. Kheirandish-Gozal L, Dayyat EA, Eid NS, Morton RL, Gozal D. Obstructive sleep apnea in poorly controlled asthmatic children: effect of adenotonsillectomy. Pediatr Pulmonol. 2011;46(9):913-918.

41. Redline S, Tishler PV, Schluchter M, Aylor J, Clark K, Graham G. Risk factors for sleep-disordered breathing in children: associations with obesity, race, and respiratory problems. Am J Respir Crit Care Med. 1999;159(5 Pt 1):1527-1532.
42. Levin JC, Gagnon L, He X, Baum ED, Karas DE, Chupp GL. Improvement in asthma control and inflammation in children undergoing adenotonsillectomy. Pediatr Res. 2014;75(3):403-408.

43. Asher MI, Keil U, Anderson HR, et al. International study of asthma and allergies in childhood (ISAAC): rationale and methods. Eur Respir J. 1995;8(3):483-491.

44. Gozal D, Shata A, Nakayama M, Spruyt K. Seasonal variability of sleep-disordered breathing in children. Pediatr Pulmonol. 2011; 46(6):581-586.

45. Marcus C, Chapman D, Ward S, et al. Clinical practice guideline: diagnosis and management of childhood obstructive sleep apnea syndrome. Pediatrics. 2002;109(4):704-712.

46. Marcus CL, Brooks LJ, Draper KA, et al. Diagnosis and management of childhood obstructive sleep apnea syndrome. Pediatrics. 2012;130(3):576-584.

47. Brockmann PE, Bertrand P, Castro-Rodriguez JA. Influence of asthma on sleep disordered breathing in children: a systematic review. Sleep Med Rev. 2014;18(5):393-397.

48. Gozal D, Sans Capdevila O, Kheirandish-Gozal L. Metabolic alterations and systemic inflammation in obstructive sleep apnea among nonobese and obese prepubertal children. Am J Respir Crit Care Med. 2008;177(10):1142-1149.

49. Malakasioti G, Gourgoulianis K, Chrousos G, Kaditis A. Interactions of obstructive sleep-disordered breathing with recurrent wheezing or asthma and their effects on sleep quality. Pediatr Pulmonol. 2011;46(11):1047-1054.

50. Nayak AS. A common pathway: asthma and allergic rhinitis. Allergy Asthma Proc. 2002;23(6):359-365.

51. Gozal D. Pediatric OSA: a case for "united we stand" in the way of a breath. Pediatr Pulmonol. 2010;45(12):1151-1152.

52. Kalra M, Lemasters G, Bernstein D, et al. Atopy as a risk factor for habitual snoring at age 1 year. Chest. 2006;129(4):942-946.

53. Arens R, Marcus CL. Pathophysiology of upper airway obstruction: a developmental perspective. Sleep. 2004;27(5):997-1019.

54. Kaditis AG. Urine concentrations of cysteinyl leukotrienes in children with obstructive sleep-disordered breathing. Chest. 2009;135(6):1496.

55. Dayyat E, Serpero LD, Kheirandish-Gozal L, et al. Leukotriene pathways and in vitro adenotonsillar cell proliferation in children with obstructive sleep apnea. Chest. 2009;135(5):1142-1149.

56. Kaditis AG, Ioannou MG, Chaidas K, et al. Cysteinyl leukotriene receptors are expressed by tonsillar $\mathrm{T}$ cells of children with obstructive sleep apnea. Chest. 2008;134(2):324-331.

57. Brouillette RT, Manoukian JJ, Ducharme FM, et al. Efficacy of fluticasone nasal spray for pediatric obstructive sleep apnea. J Pediatr. 2001;138(6):838-844.

58. Zhang L, Mendoza-Sassi R, César J, Chadha N. Intranasal corticosteroids for nasal airway obstruction in children with moderate to severe adenoidal hypertrophy. Cochrane Database Syst Rev. 2008;(3): $2-4$.

59. Goldbart AD, Goldman JL, Veling MC, Gozal D. Leukotriene modifier therapy for mild sleep-disordered breathing in children. Am J Respir Crit Care Med. 2005;172(3):364-370.

Journal of Asthma and Allergy

\section{Publish your work in this journal}

The Journal of Asthma and Allergy is an international, peer-reviewed open-access journal publishing original research, reports, editorials and commentaries on the following topics: Asthma; Pulmonary physiology; Asthma related clinical health; Clinical immunology and the immunological basis of disease; Pharmacological interventions and

new therapies. Issues of patient safety and quality of care will also be considered. The manuscript management system is completely online and includes a very quick and fair peer-review system, which is all easy to use. Visit http://www.dovepress.com/testimonials.php to read real quotes from published authors. 